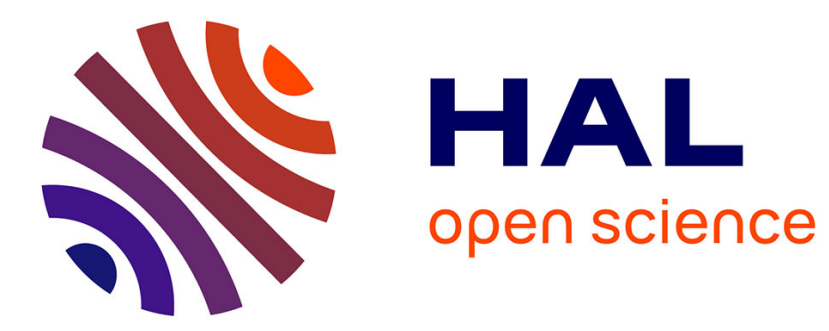

\title{
Effect of sex and genotype on protein metabolism parameters in the liver of the young goat
}

Sj Rosochacki, K Bidwell-Porebska, J Piotrowski, J Poloszynowicz

\section{To cite this version:}

Sj Rosochacki, K Bidwell-Porebska, J Piotrowski, J Poloszynowicz. Effect of sex and genotype on protein metabolism parameters in the liver of the young goat. Annales de zootechnie, 1995, 44 (Suppl1), pp.290-290. hal-00889449

\section{HAL Id: hal-00889449 \\ https://hal.science/hal-00889449}

Submitted on 1 Jan 1995

HAL is a multi-disciplinary open access archive for the deposit and dissemination of scientific research documents, whether they are published or not. The documents may come from teaching and research institutions in France or abroad, or from public or private research centers.
L'archive ouverte pluridisciplinaire HAL, est destinée au dépôt et à la diffusion de documents scientifiques de niveau recherche, publiés ou non, émanant des établissements d'enseignement et de recherche français ou étrangers, des laboratoires publics ou privés. 


\title{
Effect of sex and genotype on protein metabolism parameters in the liver of the young goat
}

\author{
SJ Rosochacki, K Bidwell-Porebska, J Piotrowski, J Poloszynowicz
}

Polish Academy of Sciences, Institute of Genetics and Animal Breeding. Jastrzebiec, 05-551 Mrokow, Poland

Feed intake proved lower while feed efficiency higher in Polish White (PW) compared to $F 1$ (Boer $\times$ PW) kid goats. Both indicators proved higher in males than in females. These may be explained by possible differences in energy and nitrogen utilization. Because contribution of liver to total energy expenditure and to total protein synthesis in the whole body is important in other animal species, the objective of this study was to relate differences in growth between genotypes and sexes to possible differences in the liver nitrogen metabolism of the goat.

Local PW male and female kid goats were compared with $\mathrm{F} 1$ Boer $\times \mathrm{PW}$ crossbreds. All the animals were group fed a milk replacer ad lib from the 2 nd day of life to a live weight of 17 $\mathrm{kg}$ and then slaughtered. RNA and DNA content $(\mathrm{mg} / \mathrm{g}$ wet tissue) were determined in the liver according to Munro and Fleck (1966, Methods Biochem Anal, 14, 113-176), while protein content ( $\mathrm{mg} / \mathrm{g}$ wet tissue) was measured according to Lowry (1951, J Biol Chem, 173, 265-275). Protein synthesis capacity (PSC) and functional cell size (FCS) were expressed as RNA/protein and protein/DNA ratios, respectively.
Within both sexes the crossbreeds had higher daily gains than the PW kids. This was clearly caused by the greater appetite of crossbreds and was reflected in the length of the fattening period. The differences in PSC between sexes were more pronounced in the crossbred $(23 \%)$ than in the PW kids $(11 \%)$, but in both cases were in favour of males. The FSC was higher in females only in PW kids, while protein content was higher in females of both genotypes. The protein content in the liver in both genetic groups was higher in females than in males. Significant differences between the genetic groups were observed for al! four indicators examined. Protein content, DNA content and FCS were higher in crossbreds, but PSC was higher in PW kids. Thus, despite a lower PSC the crossbreds accumulated more protein in the liver, what was reflected in the FCS and corresponded to their higher liver, what was reflected in the FCS and corresponded to their higher live weight gains. The above differences may arise from the proteotytic environment or concentration of proteinases as the overall determinant of the degradation rate in the cell. Proteolytic activity is currently being examined.

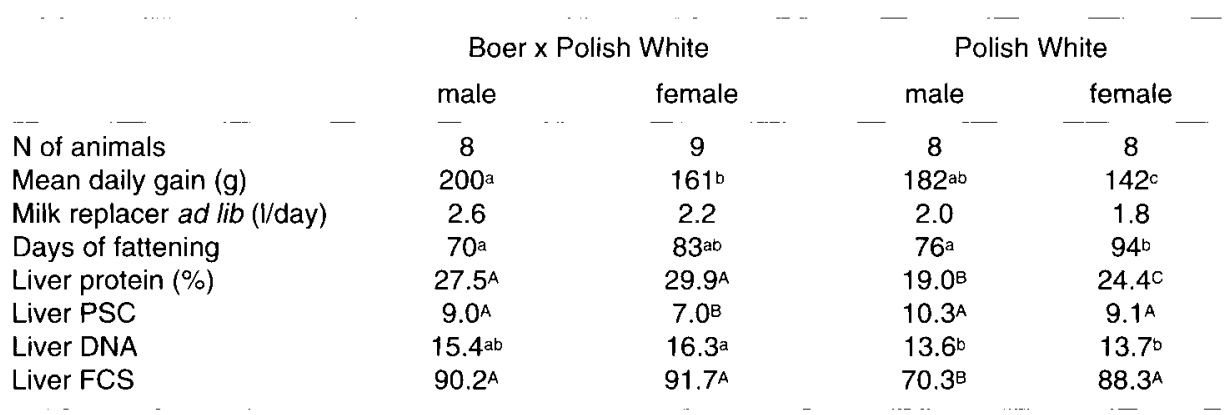

Within the row means marked with different letters differ significantly : small letters - at $\mathrm{P} \leq 0.05$, capitals $-P \leq 0.01$. 